\title{
An Analysis of Challenges of Paris Agreement on Climate Change after the United States' Withdrawal: Emerging Role of EU, China and India
}

\author{
Pradeep S. Chauhan ${ }^{1}$
}

\begin{abstract}
The United States played a key role in clinching the Paris Agreement and in expediting the satisfaction process to facilitate the execution of the agreement as early as possible. The current political dispensation is not inclined to meet its previous commitment to reduce its $\mathrm{CO}_{2}$ emissions by 26 to 28 percent in 2005. The decision to withdraw of the US government has impelled decision makers around the world to reiterate their commitment to implement the Paris agreement. The European Union (EU) will have to assume a pro-active role in the long process of implementing the promises made in Paris. In view of the unwillingness of the United States to abide by its commitment the EU needs to fortify its strategic partnerships with other major emitters such as China and India. The objective of this paper is also to discuss that how the key players will cope with the emerging situations.
\end{abstract}

\section{Introduction}

At the climate change conference in Paris in December 2015, an agreement was concluded contains goals and mechanisms to cope with the climate change and binding obligations for all Parties concerned. The Paris Agreement came about negotiations carried out in the wake of the under the United Nations Framework Convention on Climate Change (UNFCCC) and is wider in scope than the Kyoto Protocol, which committed only a limited number of parties to reduce their greenhouse gas emissions. The Paris Agreement sets out a long-term goal of redistricting the rise in the global average temperature to well below 2 degrees Celsius above pre-industrial levels, and of making efforts to confine this rise in temperature to 1.5 degrees $\mathrm{C}$. It also aims at increasing the ability to adapt to the adverse impacts of climate change and to make finance flows in sync wise a pathway towards low greenhouse gas emissions. To accomplish these goals, the Paris Agreement calls upon all Parties to make efforts towards reaching global peaking of greenhouse gas emissions as early as possible and towards achieving a balance between anthropogenic emission by sources and removals by sinks in the second half of the $21^{\text {st }}$ century. Parties make the choice of efforts and measures themselves (the so-called Nationally Determined Contributions, NDC), but the Paris Agreement spells out a mechanism of gauging progress and increasing global ambition over time by a regular "Global Stock Take". Apart from climate change mitigation, the Paris Agreement aims at improving adaptive capacity, fostering resilience and reducing the susceptibility to climate change. The Agreement also takes cognizance of the importance of

1 Dr. Chauhan is a Visiting Professor of Economics in University of California, Berkeley, CA, USA. Email: Pchauhan@kuk.ac.in 
addressing loss and damage caused by the adverse effects of climate change. The Agreement specified comprehensive provisions with regard to the support to be extended to developing countries, which incorporate finance, technology development and transfer, and capacity building. To ensure transparency in such actions and support, the Agreement sets out a number of reporting provisions. The Paris Agreement encompasses the period from 2020 onwards. Besides, the Conference of the Parties agreed on specific activities for the period before 2020 comprising the promotion of and an exchange on mitigation and adaptation actions. It is worth nothing that, according to recent studies, rise in temperature by the end of the $21^{\text {st }}$ century is expected to be close to 3 -degree $\mathrm{C}$ given the currently pledged mitigation contributions. Therefore, more extensive and intensive mitigation efforts need to be made to accomplish the temperature goal of the Paris Agreement. To bring the Paris Agreement into effect, many governments emphasized the urgent need for action in the year ensuring the adoption of the Paris Agreement. Many Parties ratified the Agreement during the year 2016, including China, India, the USA, the European Union and many of many of its Member States. The Agreement came into force on $4^{\text {th }}$ November 2016. Shortly thereafter, delegates were invited for a climate change conference in Marrakesh to discuss the details concerning the implementation of the Agreement. The included the contents of the Nationally Determined Contributions, cooperative mechanisms, reporting obligations and the preparation for the global stock take, including a "Facilitative Dialogue" scheduled for 2018. Negotiations were carried out in May 2017 and were brought up again at the conference in Bonn in November 2017, presided over by the Republic of Fiji.

\section{New Emerging Challenges}

Assessing the damage, the role of the main parties and groups of parties the year 2017 saw new challenges emerging, when the President Donald Trump made the announcement that the United States of America would withdraw from the Paris Agreement. Although the USA withdrawal will not come into effect until late in 2020 US mitigation measures and the financial support the United States extends to developing countries will face setback. China outstripped the US as the world's largest emitter of greenhouse gases in 2005. It has witnessed a strong emission growth over the past 15 years, but its $\mathrm{CO}_{2}$ emission declined slightly in 2015. The recent expansion of solar and wind energy will help gravitate towards China's goal of reversing its $\mathrm{CO}_{2}$ emission trend. After China and the United States, the European Union ranks there in terms of the emission of greenhouse gases in huge proportions. It is currently preparing climate and energy policies to meet the Union's climate change mitigation commitments by 2030 . In the climate negotiations, Parties holding similar views often put forth their positions in a coordinated and well orchestrated. A huge number of developing countries are represented by the group of "G-77 and China". On the other hand, the USA sides with developed countries in the so-called Umbrella Group. Other negotiating groups include, among others, associations of developing countries, regional associations of countries, and the Alliance of Small Island States. Other stakeholders and groups of countries besides the parties and groups of parties, also play a significant role in the run-up to and during climate change conferences, as they voice their positions and their support for specific negotiating topics. Among the non-governmental organizations (NGOs), environmental NGOs have been actively raising their concerns and expressing their views from the beginning of the climate change negotiations. Other large groups of NGOs include research/independent NGOs and business and industry NGOs. Apart from the main negotiating groups other groups of countries also evince their interests as they develop coordinated approach and their messages preceding the climate change conference. In 2017, 
climate change was a main issue at the meetings of the 'Group of Seven (G7)' and the 'Group of Twenty (G20)', where the division over climate change issues between the United States and other major economies surfaced. Moreover, there are international organizations with close links to climate negotiations, such as the Intergovernmental Panel on Climate Change (IPCC) and the International Civil Aviation Organization (ICAO) which have been approached under the Paris Agreement to furnish scientific and relevant information on future emission pathways.

\section{Will the Paris Agreement Sustain its Spirit and Buoyancy?}

The USA withdrawal from the Paris Climate Agreement was not abrupt or totally unexpected. President Trumph has his own reservation and skepticism about climate change, he once claimed that global warming was a hoaxor charade contrived by the Chinese, and promised to revive the coal industry on many occasions. The man now heading the Environmental Protection Agency (EPA), Scott Pruitt, filed 14 lawsuits while previously serving as Attorney General of Oklahoma, challenging the EPA regulations, including the Clean Power Plan (CPP). If so, the decision announced on June $1^{\text {st }}, 2017$ to withdraw from the Paris Agreement is in consonance the promise that President Trump made as a presidential candidate to cancel the agreement. At the announcement, President Trump advanced the plea that the Paris Agreement would cause the loss of 2.7 million US jobs by 2025 , including in the coal and manufacturing industries, while other countries are going to be benefitted at the expense of the United States.

\section{Some Immediate Reactions in the US after Withdrawal from the Paris Agreement}

A paper was published in Nature with a view to putting together previous findings of Climate change on the economy. Researchers from the University of California at Berkeley and Stanford maintain that dire consequences for the global economy would follow if the current pace of climate change remained unabated.

"If future adaptation mimics past adaptation, unmitigated warming is expected to reshape the global economy by reducing average global incomes roughly 23 percent by 2100 and widening global income inequality, relative to scenarios without climate change", said the paper from Marshall Burke, Solomon M. Hsiang, and Edward Miguel.

No doubt, the effects of climate change would vary from country to country; the researchers estimated that US GDP between 2016 and 2099 would be 36 percent lower if climate trends continue, in relation to a no perceptible change in temperatures. This is not to say that the other nations in the Paris accord are not able to alleviate these effects, or that Trump could not devise other measures to reduce carbon emissions. Apart from the macro economic effects, Trump said that the move would help to prevent the loss of jobs at power plants, coal mines, and other fossil-fuel-generating industries. While undeniably, a huge number of workers are engaged industries according to the Department of energy, the number of American engaged in energy-efficient and renewable energy jobs is also sizeable. For instance, 1.1 million Americans an absorbed in electric-power generation through traditional fossil fuels, but renewable also don't leg behind much with 880,000 employees. Additionally, from a long term economic standard point switching renewable energy engaged likely be more beneficial in the context of job growth. The Department of Energy said the renewable sector is progressing rapidly with solar employment growing by 25 percent and wind generation employment growing by 32 percent in 2016. Moreover, 2.2 million people are employed in the "the design, installation, and manufacture of Energy Efficiency products 
and services", and its irrefutably true climate change is a big employment generator for the USA. Morgan Stanley equity strategist Eva Zlotnicka says the job losses in fossil fuels are going to escalate irrespective of Trump's policies.

Given much of this research, a large number of business leaders berated Trump's rumored decision before his announcement. Twenty-eight major US companies - including Apple, Gap, Face book, Google, Microsoft, and Morgan Stanley -took out a full-page ad in the New York Times asking Trump not to withdraw Paris Agreement. Both Exxon Mobil and Conoco Phillips, two of the largest energy companies in the world, have also favored and endorsed the Paris Accord.

General Electric CEO, Jeff Immelt tweeted his resentment and disappointment after Trump's announcement. "Disappointed with today's decision on the Paris Agreement," Immelt said "Climate change is real; Industry must now lead and not depend on government".

This decision contrasts sharply against the leadership role that the USA played in preparing for the signature and ratification of the agreement. Its alliance with China has been critical carrying out a successful deal in Paris. Moreover, Presidents Obama and Xi's joint ratification of the agreement on $3^{\text {rd }}$ September 2016 induced others to follow, including the EU, facilitating a huge response in favor of be playing agreement. On this occasion, the EU seemed to be not in a leading role but in a supporting one. With its credibility, it had to agree on a fast track procedure with a final vote from the European parliament on $4^{\text {th }}$ October 2016 rather than wait for each member state to ratify the agreement individually. The agreement having been ratified by 153 of the 197 Parties, has reached to its implementation phase. Countries are discussing how to attain the objectives set out in Paris accord to the global average temperature increase to well below $2^{\circ} \mathrm{C}$ above pre-industrial at levels and try to restrict this rise to $1.5^{\circ} \mathrm{C}$.

\section{The Paris Agreement under UNFCCC}

The President Trump proposed in his 2018 'America First' budget to eliminate the Global Climate Change Initiative (GCCI), which was undertaken by his predecessor to divert money to the UNFCCC. The USA currently provides 20 percent of the UNFCCC's annual budget. The GCCI also contributes to financing the Intergovernmental Panel on Climate Change (IPCC), which provides scientific inputs on climate change, to the policy makers for its impact and future risks. The IPCC has encountered difficulties in raising funds in recent years, garnering only $\$ 4.3$ million from donor countries and various UN bodies, including the UNFCCC as compared to more than $\$ 7$ million on 2013. This is a matter of serious concern as the scientific information provided by the IPCC has been an important catalyst for political action. Lastly, the GCCI also delivers funds to the Montreal Protocol, the international treaty designed to phase out substances that deplete the ozone layer.8 on $15^{\text {th }}$ October 2016, 197 countries, including the USA, entered into an agreement the production and consumption of hydro fluorocarbons (HFCs) by more than 80 percent over the next 30 curtail years to lessen temperature change by 2100 by an estimated $0.5^{\circ} \mathrm{C}$. It is now uncertain whether the USA will renege on this commitment or abide by it.

\section{National Climate Policies in the US and Paris Agreement}

To achieve the goals set in Paris it is incumbent upon all the countries to reduce their emissions. It is more imperative upon the large emitters, including the USA which alone is 
responsible 14.36 percent of global greenhouse gas emissions, the second largest after China. In Article 4 of the Paris Agreement stipulates that countries are to implement their Nationally Determined Contributions (NDCs). It is the climate actions they intend to put in place after 2020 to contribute to the global effort to attain the Paris objectives.

The US government has no intention to fulfill the NDC presented by the previous administration to reduce $\mathrm{CO}_{2}$ emissions by 26-28 percent from 2005 levels by 2025 . On the contrary, President Trump debunks the climate change policies of his predecessor. Its Executive order on Energy Independence calls for the re-assessment of the CPP, with a view to eliminating it completely. The CPP, which aimed to reduce $\mathrm{CO}_{2}$ emissions by 32 percent (below 2005 levels) by 2030, was one of Obama's main instruments for implementing the NDC. The plan, currently stalled by the Supreme Court at the request of 27 states and several companies, has never been executed. To attain the goals set by the USA require the implementation of the plan but also more sustained and ambitious climate policies.

\section{The EU's Role Through Strategic Partnerships}

Far from dampening the spirit, the announcement of the USA withdrawal promoted policy makers around the world to unambiguously reiterate and reinforce their intention to implement the Paris Agreement. The EU reacted promptly to the many statements by Member States, including a joint statement from France, Germany and Italy, stating that "the Paris Agreement is a vital instrument for our planet, our societies and our economies "(European Commission New Archives)., In its conclusions adopted on $22^{\text {nd }}$ and $23^{\text {rd }}$ June 2017, the European Council reiterated and reaffirmed the commitment of the EU and its member States to implement the Paris Agreement "Swiftly and Fully, to contribute to the achieving climate finance goals and continuing to fight climate change". "Similarly, Miguel Arias Cañete, Climate and Energy Commissioner for Action, said" the world can continue to count on Europe for global leadership in the fight against climate change "(UNFCCC Secretariat), in order to achieve this goal.

\section{Role of EU, India and China, the Major Emitters}

Given the reluctance of the USA to participate in global efforts, it becomes more important for the EU to work with its strategic partnerships other major emitters such as China or India. China, being the world's largest emitter (responsible for 26.83 percent of global greenhouse gas emissions), is committed to reducing $\mathrm{CO}_{2}$ emissions per unit of GDP by 60 to 65 percent from the 2005 level of here 2030. By developing partnership with China, the EU can lead the global transition to a low-carbon economy.

There are multiple possible ways of cooperation between the EU and China. The European Commission's Joint Communication 'Elements for a new EU strategy on China mentions that the EU needs to continue supporting China on emission trading, increase dialogues in areas such as climate policymaking and emissions modeling, low carbon cities, low carbon technologies, carbon capture and storage, adaptation, and climate resilient investments.

The case of the Environmental Goods Agreement (EGA) points out that the shared willingness to pursue climate change mitigation objectives could lead to expanded trade between both partners, thus combining environmental and economic gains. The EGA, which is currently being negotiated by 14 WTO members (including the EU, China, the US, Japan, Canada, Australia, Switzerland, south Korea and Norway) aims to curtail tariffs on a list of 
products that can contribute to environmental protection and climate change mitigation, such as heat pumps, wind turbines and solar panels. The negotiations are currently thwarted due to disagreements on the final list of products that should be included in the agreement. A closer partnership between the EU and China on climate action could help resolve this stalemate. The EU and the other countries involved in the negotiations bring round the USA to continue to stay in the EGA as well.

Besides, this EU also needs to reinforce its partnership with other big players like India. India is the fastest growing economy, accounting for 6.65 percent of global emissions. Its emissions escalated by 67.1 percent between 1990 and 2012. In 2015, India announced an ambitious goal to enhance its renewable power capacity five times by 2022 . The growth of the renewable energy sector combined with a reduction in coal development will enable India to achieve more than its 2030 NDC emissions intensity target. On $31^{\text {st }}$ March 2016, the EU and India adopted a Joint Declaration on a clean energy and climate partnership, which visualizes cooperation on energy efficiency in buildings, development of renewable energy sources, smart grids, energy research and innovation. Although Indian energy minister Piyush Goyal said that "India stands committed to its commitments made in Paris irrespective of what happens in the rest of the world". The country made it clear when signing the Paris Agreement that its involvement was subject to financial assistance from other major economies. On hearing this statement, Germany offered more than $€ 2$ billion in October 2015 for the development of a clean energy corridor and solar projects in India. Chancellor Angela Markel also promised $€ 1$ billion of development assistance on $30^{\text {th }}$ May 2017.32 The EU should also use its development policies to enhance its support to decentralized renewable energy projects in informal urban settlements and rural areas in the country (Economic Times).

The recent G7 and G20 offered opportunities for the world's largest economies to deliver a collective call for climate action. But the G7 summit held on 26-27 May pitted President Trump against other world leaders. This rift was evident in the final declaration of the G20 summit held on $7^{\text {th }}-8^{\text {th }}$ July 2017 , which revered green forced the commitment of all members of the G20 except the US, to swiftly implement the Paris agreement, stating it was "Irreversible". The declaration also felt concerned about the decision made by the US to withdraw from the Paris deal and not to implement its current NDC. Leaders, furthermore, recognized that investments into sustainable energy sources and clean energy technologies and infrastructure can pave the way for growth, enhanced job opportunities and competitiveness (G20, 2017).

The EU must make strenuous efforts to stall the contagious risk by ensuring the other countries do not copy the USA. In this regard, persuading Russia to expedite its ratification process, currently planned for 2019 , is of critical importance. As one of the world's largest emitters and fossil fuel producers, Russia can play a significant role in respect of climate change mitigation. However, its NDC to lower greenhouse gas emission by 25-30 percent has compared to 1990 levels by 2030 , a target which considers the maximum absorbing capacity of its forests, is abysmal (G20, 2017).

\section{Fund}

Support of Developed Countries to Developing Countries through Green Climate

The new climate regime puts the onus on the developed countries to provide support to developing countries to enable them to pursue climate mitigation and adaptation projects. Advanced economies therefore promised to earmark $\$ 100$ billion per year by 2020 to realize 
this goal. These financial resources are routed through the Green Climate Fund (GCF). By May 2017, the GCF has raised $\$ 10.3$ billion in pledges from 43 state governments. The USA pledged $\$ 3$ billion, which represents the highest contribution and twice that of the secondlargest pledger, Japan. The Obama administration transferred $\$ 1$ billion, $\$ 500$ of which three days before quitting office. But the Trump administration has announced its decision to repudiate the US contributions to the fund leaving an unbudgeted gap of $\$ 2$ billion. This sends a dampening message to developing countries, which bank upon developed countries to help them implement their NDCs. As the US is no longer a reliable partner in multilateral climate politics, it is more imperative on the part of the EU to provide consistently abundant support to these countries.

The EU and its member states have been providing substantial financial support, spending $€ 17.6$ billion in 2015 along with the European Investment Bank (EIB), to help developing countries to cope with climate change (EU, 2016). The EU also deserves appreciation for having agreed to augment cooperation to promote low-emission, climateresilient development with 79 other countries at the Bonn Conference May $18^{\text {th }} 2017$. During the conference, the EU also pledged to provide $€ 800$ million for the Pacific region up to 2020 .

The Paris Agreement is a dynamic process containing provisions for raising ambition of its parties. It establishes an ongoing, regular process to mount up action known as the Ambition Mechanism. Countries will meet every five years to take stock of global implementation and collective progress, and the countries will be required to submit updated NDCs based on this stock fulfilling its pledges to be a global leader.

The EU needs to ensure the achievement of the $1.5^{\circ} \mathrm{c}$ target throughout this dynamic process by fulfilling its pledges which the vulnerable countries can rely on. Only then can the EU emerge as the global leader.

Figure 1. Effect of Current Pledges and Policies on Global Temperature

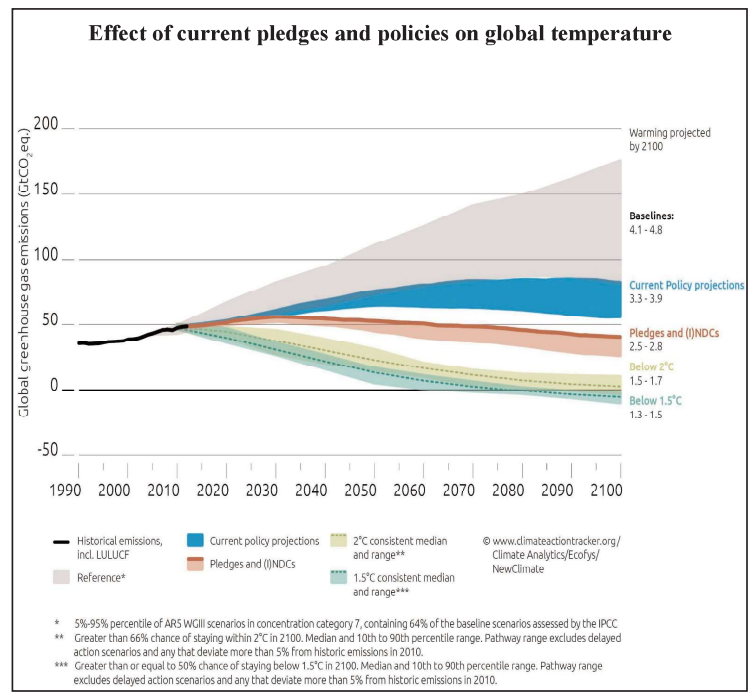

Source: Climate Action tracker (2016). Available at: http://climateactiontracker.org/global.html, last accessed on 11 July 2017. 
The EU and its members should also ensure coordination and synergy between their development and climate policies. The $15^{\text {th }}$ February 2016 Council Conclusion on "climate diplomacy after COP21" state that "the EU and Member States development cooperation with third countries should fully take into account the existing synergies between climate objectives and the sustainable development goals as adopted by the 2030 Agenda for Sustainable Development and other international agendas (General Secretariat of the Council, 2017). Under that logic the EU needs to support developing countries to implement Sustainable Development Goal 7 to "ensure access to affordable, reliable and modern energy for all" in a way that fills with the targets set in Paris, including members of the CVF that pledged solely depend upon renewable energy by 2050. The European External Investment Plan, which aims to provide fillip to private investments in developing countries, can be used to finance renewable energy, and low-carbon and energy efficient projects.

\section{Assessment of the Effect of Current Policies on Global Temperature Efforts for Strengthening Ties with US sub national Actors}

The US government's position on climate change is not reflective of the position of a considerable number of US states and cities. Several states have made tremendous efforts to switch over to renewable energy in a big way and have initiated concrete measures to reduce their emissions. California, the world's sixth-largest economy, generated 25.45 percent of its energy from renewable sources in 2016 (California Energy Commission, 2016). In 2016, the government having enacted a law requiring greenhouse gas emissions to be 40 percent below normal levels. 1990 by 2030, which approximates to the EU target. California has also setfuel economy standards surpassing federal requirements, which have been adopted by a dozen other states subsequently. The example of Texas shows that arguments in favor of renewable energies cut across party lines. The Republican State and despite being rich in oil is still the national leader in wind power generation. With 11592 turbines, Texas has three times the capacity of neighboring Iowa, which represents 12.68 percent of its energy production (Dart \& Milman, 2017). It needs to be noted that investments began under the leadership of two Republican figures, George W. Bush and Rick Perry, the current US Secretary of Energy, States also voice their opposition to decisions taken by the federal executive. The executive decree on energy independence has already triggered hostile reactions from a coalition of states and local governments. Reacting the withdrawal from the Paris agreement, a group of representatives from states, cities, businesses, investors and academia presented an open letter entitled 'We are still in' to the international community, pledging to support and pursue ambitious climate goals oblivious of the policies adopted by Washington and to remain actively associated with the international community. The group includes cities such as Los Angeles, Atlanta and Pittsburgh, whose mayor, Bill Peduto, recently announced that the city aims to switch over to 100 percent renewable energy by 2035 (Climate Action, 2017). Another initiative called the ZUS Climate Alliance brings together thirteen states, accounting for 102 million people and one third of the country's GDP, to pursue the objective of lowering $\mathrm{CO}_{2}$ emissions by 26 percent to 28 percent by 2025 compared to 2005 levels (Rice, 2017).

The example of California shows that subnational actors are willing to play an active role in the field of climate diplomacy despite the withdrawal of the USA from the Paris Agreement. The state is strengthening its relations with Canada and Mexico. The partners recently inked a voluntary pact to lower greenhouse gas emissions, which could lead to cooperation in developing and aligning carbon pricing systems. California has already developed a cap and trade market that is connected to a similar one in Quebec. The Province 
of Ontario will link to both systems next year. California will also cooperate with China on emissions trading and is developing partnerships with Chinese Provinces. On $5^{\text {th }}$ June 2017 the US state entered into an agreement with the Chinee Province of Jiangsu, establishing a Clean Technology Partnership to boost cooperation on research, innovation, and investment in low-carbon development and clean energy resources.

Moreover, Trump's claim that lowering greenhouse gas emissions causes a competitive disadvantage and undermines economic growth are rebutted by economic realities. In fact, 33 states severed their growth and carbon emissions between 2000 and 2014 (Saha \& Muro, 2016 ) and investments in renewable energy, which reached $\$ 44.1$ billion in 2015 , are set to continue. According to projections made by the US Energy Information Administration (EIA), even if the CPP is never implemented, the share of energy from renewable sources would still increase by 3.9 percent a year between 2015 and 2030, as compared to 0.6 percent for natural gas 55 . This trend partly emanates from a decision made by the US Congress in December 2015 to extend federal tax credits for wind and solar energy projects until 2020.

Figure 2. U.S. Net Electricity Generation by Fuel (1990-2040) Billion Kilo Watt Hours

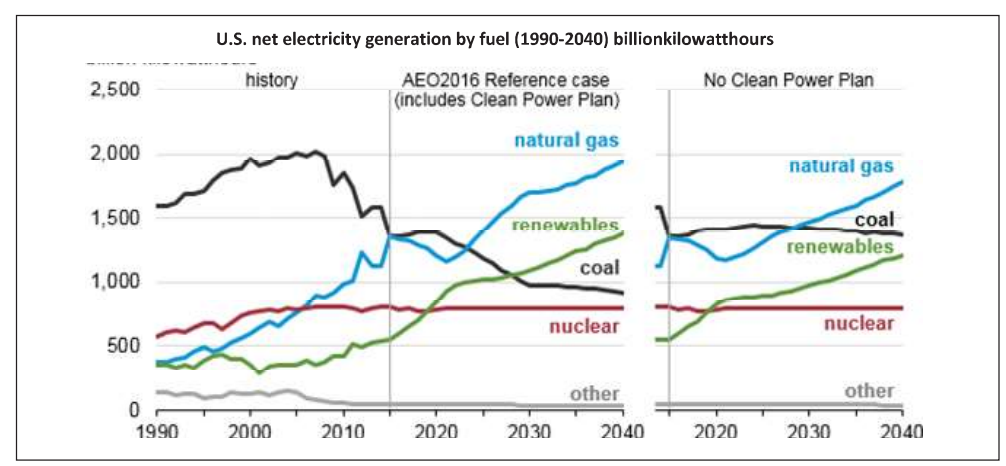

Source: Huetteman, Thad \& Martin, Laura, EIA. Available at https://www.eia.gov/todayinenrgy/detauk.php?ud=26712

These developments provide propitious situations to the EU to strengthen its cooperation with US states and cities. Given California's position as a frontrunner, the EU could start strengthening its ties by signing an agreement like the ones California has signed with countries like Mexico, Canada and China. The EU could also cooperate with the members of the US Climate Alliance in various spheres such as low-carbon technologies and low carbon mobility. The EU should furthermore do cooperation between subnational actors in Europe and the US. On this matter, the Global Covenant of Mayors for Climate \& Energy initiative, which embraces a total of 7453 cities and 9.39 percent of the world's population, forms an important platform to nurture cooperation between American and European cities and given spurt to locally led climate action. The global coalition aims to promote and support voluntary action to stall climate change and move to a low-carbon economy. Commission Vice President Maros Sefcovic emphasized that the role of the organization and local authorities had become even more crucial since the US withdrawal and urged other local leaders to join the initiative (Gotev, 2017). 


\section{Conclusion}

The current reluctance of the US government to participate in the collective effort to restrict escalating global temperatures and cope with the effects for climate change is a big impediment to the implementation of the Paris Agreement, yet it is not insurmountable. Many statements that followed the withdrawal of the United States show that there is strong political will among world leaders to honor their climate commitments. Besides, the transition to a low-carbon economy has already begun with the realization that mitigation of climate change can give a fillip to economic growth and job creation. The current dynamics of international climate action and inspire optimism.

However, the implementation of the Paris Agreement will require sustained and ambitious political action with renewed zeal in view of the fact by all countries especially that the USA has decided to leave it. The EU is expected of assuming a leading role in the implementation of the agreement by fostering existing partnerships and forging new ones. It must cooperate with major emitters and other developed countries to ensure that they adopt and implement measures to decarbonizes their economies in a manner which is insync with the objectives set in Paris. To do this, the EU must use various international bodies, including the $\mathrm{G} 20$, as platforms to promote international climate governance. At the same time, the EU must continue providing financial support to developing countries to facilitate the implementation of climate change mitigation and adaptation projects and create synergies between climate and development goals. Considering that the participation of all countries is critical to achieve the goals set in Paris, the EU must ensure that countries do not follow the example of President Erdogan and use the withdrawal of the United States as an execute to renege on their commitments.

The withdrawal of the United States has also given a better insight into the critical role of sub national actors in achieving the goals setin Paris. If it is impossible to bring sowed President Trump to continue to stay in the Paris Agreement, the EU, China and India can stillboost climate change mitigation in the United States by establishing partnerships with states like California or members of the USA. American Climate Alliance can facilitate cooperation between USA and European cities through the Global Covenant of Mayors for Climate \& Energy imitative. Strong and dynamic leadership from the EU, China and India is as important as the "Regulation" for implementation of the Paris Agreement.

\section{References}

Balmer, C., King, L., \& Reinhold, T. (2017). France, Italy, Germany defend Paris Accord, say cannot be renegotiated, $I^{s t}$ June 2017. Available at http://www.reuters.com/article/us-usaclimatechange-eu-idUSKBN18S6GN.

California Energy Commission (2016). Total System Electric Generation. Available at http://www.energy.ca.gov/almanac/electricity_data/total_system_power.html, last accessed.

California Legislative Information (2016). SB-32 California Global Warming Solutions Act of 2006: Emissions Limit. Available at https://leginfo.legislature.ca.gov/faces/ billNavClient.xhtml? bill_id=201520160SB32, last accessed.

Chaudhury, D. R. (2015). Germany extends \$1 billion assistance to India. The Economic Times, [date?], available at http://economictimes.indiatimes.com/news/politics-and-nation/narendramodi-in-germany-angela-merkel-extends-1-billion-assistance-to-india-pm-for-jointly-fightingterrorism/articleshow/58916416.cms.

(2015). Germany extends $\$ 2.25$ billion support to India for clean energy corridor, solar projects. The Economic Times, $6^{\text {th }}$ October 2015, available at http://economictimes. 
indiatimes.com/news/politics-and-nation/germany-extends-2-25-billion-support-to-india-forclean-energy-corridor-solar-projects/articleshow/49236058.cms.

Climate Action. Pittsburgh to aim for $100 \%$ renewable energy by 2035, $5^{\text {th }}$ June 2017. Available at $\mathrm{http} / / / \mathrm{www} . c$ limateactionprogramme.org/news/pittsburgh-commits-to-100-renewable-energyby-2035.

Climate Action Tracker (2017). Countries, Turkey, last update on $17^{\text {th }}$ July 2017. Available at http://climateactiontracker.org/countries/turkey.html.

..........Countries. Available at http://climateactiontracker.org/countries/russianfederation.html,

Climate. United Nations Environment Programme (UNEP), Ozone Secretariat, The Montreal Protocol on substances that deplete the ozone layer. Available at http://ozone.unep.org/en/treaties-anddecisions/montreal-protocol-substances-deplete-ozone-layer.

Dart, T., \& Milman, O. (2017). The wild west of wind: Republicans push Texas as unlikely green energy leader. The Guardian, 20 February 2017. Available at https://www.theguardian.com/usnews/2017/feb/20/texas-wind-energy-green-turbines-repbublicans-environment.

Donnan, S., Hornby, L., \& Beesley, A. (2017). China challenges EU and US over market economy status. Financial Times, 12 December 2016. Available at https://www.ft.com/content/6af8da62bf5d-11e6-9bca-2b93a6856354?mhq5j=e1.

European Commission (2017). Press Release Database, EU-China Summit: Moving Forward with our Global Partnership, $2^{\text {nd }}$ June 2017. Available at http://europa.eu/rapid/press-release_IP-171524_en.htm,

........(2017). Press Release Database, EU-India Summit: A New Momentum for the EU-India Strategic Partnership, 30 ${ }^{\text {th }}$ March 2016. Available at: https://ec.europa.eu/energy/en/news/euand-india-agree-clean-energy-and-climate-partnership.

European Commission. EU Demonstrates Commitment to Developing Countries by Stepping up Climate Finance to $€ 17.6 \quad$ bln", $25^{\text {th }}$ October 2016. Available at https://ec.europa.eu/clima/news/articles/news_2016102501_en.

Harvey, F. (2015). World's climate pledges not yet enough to avoid dangerous warming - UN. The Guardian, 30 October 2015. Available at https://www.theguardian.com/environment/ 2015/oct/30/worlds-climate-pledges-likely-to-lead-to-less-than-3c-of-warming-un

European Commission News Archive. The Environmental Goods Agreement (EGA): Liberalising Trade in Environmental Goods and Services. Available at http://trade.ec.europa.eu/doclib/press/ index.cfm?id=1116.

Friedrich, J., Ge, M., \& Pickens, A.(2017). This interactive chart explains world's top 10 emitters, and how they've changed. World Resources Institute, 11 ${ }^{\text {th }}$ April 2017. Available at http://www.wri.org/blog/2017/04/interactive-chart-explains-worlds-top-10-emitters-and-howtheyve-changed.

G20 (2017). G20 Leader's Declaration: Shaping an Interconnected World, Hamburg, $7^{\text {th }}-8^{\text {th }}$ July 2017. Available at https://www.g20.org/gipfeldokumente/G20-leaders-declaration.pdf.

Gotev, G. (2017). EU calls on all cities to join 'Global Covenant of Mayors'., Euractiv, $27^{\text {th }}$ June 2017. Available at https://www.euractiv.com/section/climate-environment/news/eu-calls-on-all-citiesto-join-global-covenant-of-mayors/.

Leaked Joint Statement (2017). EU-China Leaders' Joint Statement on Climate Change and Clean Energy, $2^{\text {nd }}$ June 2017. Available at https://www.scribd.com/document/350072665/FinalVersion-EU-China-Leaders-Joint-Statement-on-Climate-Change\#download\&from embed,.

Mathiesen, K. (2017). India reaffirms Paris climate commitments", Climate Home, $11^{\text {th }}$ May 2017. Available athttp://www.climatechangenews.com/2017/05/11/indian-energy-minister-reaffirmsparis-climate-commitments/.

Office of Governor G. Brown Jr. (2017). Press Release. Governor Brown Strengthens Climate Alliance with California's Sister State, Jiangsu Province, $5^{\text {th }}$ June 2017. Available at http://cert1.mailwest.com/mvZyjiM/gtmyuzjanmc7r/27b166dbk41vZ/vnqvZnu5u/41vZq/ftbbt1 yghfgbksbh?_c=d|ze7pzanwmhlzgt|14xotsutl1googs\&_ce=1496678697.fcd8302a62c7782c9f1b $3065 \mathrm{dce} 303 \overline{\mathrm{df}}$ 
Philips, T., Harvey, F., \& Yuhas, A. (2016). Breakthrough as US and China agree to ratify Paris climate deal. The Guardian, $3^{\text {rd }}$ September 2016. Available at https://www.theguardian.com/ environment $/ 2016 / \mathrm{sep} / 03 /$ breakthrough-us-china-agree-ratify-paris-climate- change-deal.

Rice, D. (2017). More states sign on to U.S. Climate Alliance to honor Paris agreement. USA TODAY. Available at https://www.usatoday.com/story/news/nation/2017/06/08/more-states-sign-usclimate-alliance-honor-paris-agreement/102629160/, last accessed.

Rice, D. (2017). More states sign on to U.S. climate alliance to honor Paris agreement. USA TODAY, $8^{\text {th }}$ June 2017. Available at https://www.usatoday.com/story/news/nation/2017/06/08/morestates-sign-us-climate-alliance-honor-paris-agreement/102629160/.

Saha, D., \& Muro, M. (2016). Growth, carbon and Trump: States are "decoupling" economic growth from emissions growth. Brookings, $8^{\text {th }}$ December 2016. Available at https://www.brookings.edu/blog/the-avenue/2016/12/08/decoupling-economic-growth-fromemissions-growth.

(2016). Growth, carbon and Trump: States are "decoupling" economic growth from emissions growth. Brookings, $8^{\text {th }}$ December 2016, available at https://www.brookings.edu/blog/theavenue/2016/12/08/decoupling-economic-growth-from-emissions-growth/.

Shwarz, T. (2017). Erdogan threatens not to ratify Paris climate accord. AFP, $8^{\text {th }}$ July 2017. https://www.afp.com/en/news/2265/erdogan-threatens-not-ratify-paris-climate-accord.

The Paris Agreement (2015). Article 28. Available at: https:/unfccc.int/files/meetings/ paris_nov_2015/application/pdf/paris_agreement_english_pdf,

(UNFCCC) (The United Nations Framework Convention on Climate Change) (2017). The Paris Agreement. Available at: http://unfccc.int/paris_agreement/items/9485.php,

(2017). India's Intended Nationally Determined Contribution: Working towards Climate Justice., Available athttp://www4.unfccc.int/ndcregistry/PublishedDocuments/India\%20 First/INDIA\%20INDC\%20TO\%20UNFCCC.pdf.

The White House, Office of the Press Secretary (2017). Statement by President Trump on the Paris Climate Accord. June 2017. Available at https://www.whitehouse.gov/the-pressoffice/2017/06/01/statement-president-trump-paris-climate-accord.

U.S Energy Information Administration (2016). Clean Power Plan Accelerates the Growth of Renewable Generation throughout United States., 17 ${ }^{\text {th }}$ June 2016. Available at https://www.eia.gov/ todayinenergy/detail.php?id=26712.

UN Environment (2016). Renewable Energy Investments: Major Milestones Reached, New World Record Set. $24^{\text {th }}$ March 2016. http://www.unep.org/northamerica/news/2016/renewable-energyinvestments-major-milestones-reached-new-world-record-set.

... (2016). Renewable Energy Investments: Major Milestones Reached, New World Record Set. 24 March 2016. http://www.unep.org/northamerica/news/2016/renewable-energyinvestments-major-milestones-reached-new-world-record-set.

United Nations Climate Change Secretariat, Emissions Summary for India. Available at https://unfccc.int/files/ghg_data/ghg_data_unfccc/ghg_profiles/application/pdf/ind_ghg_profile. pdf,

EPA (United States Environmental Protection Agency). Recent International Developments under the Montreal Protocol. Available athttps://www.epa.gov/ozone-layer-protection/recentinternational-developments-under-montreal-protocol. 